\title{
The social transmission of knowledge at the University: Teaching style and epistemic dependence
}

\author{
Gabriel Mugny \\ Armand Chatard \\ Alain Quiamzade \\ University of Geneva, Switzerland
}

\begin{abstract}
It is argued that an epistemic authority would induce greater influence in transmitting knowledge to students when there is a correspondence between the (authoritarian vs. democratic) style of the authority and students' perceptions of their relation to the authority (high vs. low epistemic dependence). In two studies it was predicted, and found, that students who perceived themselves in a state of low epistemic dependence towards their teachers were more influenced by a democratic than by an authoritarian teaching style. This difference in appropriation was not found for students who perceived themselves in a state of epistemic dependence towards the epistemic authority.
\end{abstract}

That a student's competence depends on his/her ability to admit knowledge provided by a scientific authority (i.e., a competent source) is a belief that has been shown to be accepted by first year students, more so than by fourth year students (Buchs, Falomir, Mugny, \& Quiamzade, 2002, Study 2; Quiamzade, Mugny, Dragulescu, \& Buchs, 2003). This is in line with Kitchener and King (1981) work who have shown that students at the university progressively modify their conception of knowledge. This epistemic development originates in the view that knowledge is an absolute to which epistemic authorities provide access. This suggests that students considering themselves less competent in their domain should benefit from a social influence context in which the epistemic authority guides them to the knowledge to be acquired. The epistemic development moves towards a more relativist conception, and students come to recognise that distinct, even apparently contradictory, pieces of knowledge may be valid depending on particular perspectives. Knowledge is progressively acquired via a critical examination of existing views and new evidence that is not compatible with a submissive relationship to some epistemic authority (Kitchener, King, Wood, \& Davison,

This study was part of a research program supported by the Swiss National Foundation for Scientific Research. We would like to thank Dominique Pigière (University of Toulouse) for collecting data in study 1 . 
1989). This suggests that students considering themselves more competent in their domain should benefit from a social influence context in which the epistemic authority guaranties their autonomy in knowledge acquisition.

These supposed influence dynamics correspond to a general hypothesis that appropriation of information provided by competent sources is more likely when the representation that targets have about what the relationship with the source ought to be fits with the actual relationship (Quiamzade, Mugny, Falomir, Invernizzi, Buchs, \& Dragulescu, 2004; see also Tomasetto, 2004). Indeed, this evolution parallels the fact that with increases in the years of study at the university, students are differentially sensible to the style of the epistemic authority. As a matter of fact, it has been observed (with Romanian students) that first year students appropriate more the message content when the epistemic authority employs an authoritarian style (Quiamzade et al., 2003), whereas fourth year students do not show such a difference, even if the pattern tended to be reversed. In another study (with French students) using self-competence feelings as a base of the students' subjective level of knowledge, it has been found that more competent students appropriate more the message content when the epistemic authority employs a democratic style rather than an authoritarian style whereas less competent students do not make a clear difference between the two styles in their level of message integration (Mugny, Quiamzade, Pigière, Dragulescu, \& Buchs, 2002).

It appears that French students are specifically blocked by the authoritarian style, since Quiamzade, Mugny, and Buchs (2005) reproduced these results with another French students sample using the same manipulation of the styles, but observed the expected inversion when the relationship was based on a different experimental manipulation, i.e., a more or less compelling social comparison with the source. In conditions of negative interdependence of comparison, subjects had to estimate self and source's competence by dividing 100 points of competence between themselves and the source. This represents a compelling social comparison because recognizing competence of the source implies to recognize self-incompetence: Any competence attributed to the source reduces by the same amount the competence attributed to self. In the conditions of independence of comparison, subjects had to estimate the level of self-competence from 0 to 100 and the level of the source's competence by the same way on separate scales. This comparison is less compelling in that it allows to recognize competence to the source without feeling so incompetent. Results showed that students considering themselves the less competent appropriated more the contradictory information when the social comparison was compelling, whereas students considering themselves the more competent changed more with a less compelling social comparison. In fact, the compelling social comparison introduces a threat for individuals who have some competence to defend whereas it reproduces a legitimate hierarchy between them and the highly competent source and fits with the actual relationship for the individuals feeling less competent. As a consequence, it blocked influence for the former but enhanced influence for the latter. At the opposite, the less compelling comparison produced more influence in those who wait for a relationship which respects their competence, i.e., those who feel competent.

Some data suggest indeed that intercultural differences may exist between Eastern European or "old socialist" culture and Western European culture about conformity behaviour towards powerful sources, suggesting that the former would conform more than the latter (Garbarino \& Bronfenbrenner, 1976; Shouval, Venaki, Bronfenbrenner, Devereux, \& Kiely, 1975). Romania is a country emerging from a totalitarian period in which hierarchical relations were based on powerful authority relationships. Transposed to the university context, this could mean that an epistemic authority could, or even should, exercise its power in an assertive way that is legitimated by the cultural context. This would be less a feature of the contemporary ideology of Western European universities in which democratic ideology predominates. It may be for this reason that while the democratic style was not significantly more beneficial to the Romanian fourth year students, the same style was more beneficial to the French competent students. For the latter, because the confidence in their own knowledge and ability was severely challenged by the authoritarian style, this excluded the possibility of any appropriation of the contradicting information. In this case various ingredients of an ille- 
gitimate persuasive dynamic of persuasive constraint are salient. They highlight a threat to targets' perceived competence and self-esteem (cf. Quiamzade et al., 2004), and discourage appropriation.

In fact, the probability that a specific relationship will induce appropriation of a new knowledge is a function of variations in the meaning it takes for students. It is hypothesized that the above results, even if somewhat differing due to cultural differences, are grounded in the same psychological dimension underlying the relationship with an epistemic authority and the meaning given to the different styles: The informational dependence state vis-à-vis the epistemic authority in which students can be, leading to an informational influence. Deutsch and Gerard (1955, p. 629) define informational influence as "an influence to accept information obtained from another as evidence about reality" which is related to uncertainty about self and other's judgments correctness. Corollary, informational dependence can be seen as the degree of dependence in which people under uncertainty are vis-à-vis of a recognized and accepted source whose judgments are probably correct. This means that the influence process takes place because of three reasons. First, the source is supposed to possess some appropriate resources as relevant information (Cartwright \& Zander, 1968, p. 221). Second, it is grounded on a legitimate power (French \& Raven, 1959), which implies that the source is invested by a right to influence that dictates to the target that there is some kind of necessity to accept this influence. Third, it gives to the source enough credibility, i.e., recognized expertise as well as trustworthiness (Hovland, Janis, \& Kelley, 1953), allowing for a real appropriation and integration, rather than just compliance (Kelman, 1958). In other words, informational dependence is a psychological state of the targets in which they admit the judgments provided by the competent source, whose competence is associated to others relevant factors (see McGuire, 1985) giving to the influence process the meaning of a non threatening relationship with the source (Mugny, Butera, Quiamzade, Dragulescu, \& Tomei, 2003).

For Romanian students we can suppose that the acquisition of a new knowledge the authoritarian style induces would depend on the fact that this style is not perceived as an illegitimate social influence relationship or persuasive constraint (Falomir, Butera, \& Mugny, 2002), but as a legitimate transmission-of-knowledge relationship between targets in a state of epistemic dependence and a source recognized as having epistemic authority. The epistemic dependence probably avoids the source to be perceived as threatening targets's identity (cf. Quiamzade \& Mugny, 2001), despite its authoritarian style. Epistemic dependence motivates the target to elaborate the information delivered by the competent source (Insko, Drenan, Solomon, Smith, \& Wade, 1983; Kruglanski, 1989). In this context, the democratic style could even have inhibiting properties for these subjects in a state of epistemic dependence, since appropriation is induced if the relationship with the expert source is compelling and guides the targets directly to the source's point of view, i.e., makes explicit its authority.

At the opposite, for French students, since in their social and cultural context the authoritarian style appears to introduce a strong resistance, it should induce at best as much appropriation as the democratic style, but not more, in targets who believe that their competence is a function of their ability to accept the information given by the epistemic authority, i.e., who are high in epistemic dependence. However, the style should make a difference among targets who do not share such a belief, i.e., who are low in epistemic dependence and thus need to be treated with deference and fairness (cf. Tyler, 1997). For them, a democratic style should be necessary in order to encourage them to appropriate the information, since it seems more in line with the socio-political context, while an authoritarian style should inhibit social influence since it does not correspond to these students' expectations.

A first step of demonstrations has already succeeded. A study with Romanian psychology students (Mugny, Quiamzade, \& Trandafir, 2006) confirmed that the advantage of the authoritarian style depended on the fact that students believed that their competence was a function of their ability to accept the information given by their teachers, whereas the difference between both styles disappeared for students who did not share this belief. The second step, which will concern the present paper, will consist in illustrating the validity of the 
symmetric pattern for Western students, i.e., that the advantage of the democratic style is grounded on the fact that students do not share this representation.

\section{STUDIES OVERVIEW}

In two experiments with Western university students (French in Study 1 and Swiss in Study 2) the style of teaching (authoritarian vs. democratic) was manipulated, and the perceived degree of epistemic dependence of students was measured. The style has been manipulated in the same way as in the previous experiments, and subjects were divided on the basis of their belief in the notion that their competence is (high epistemic dependence) or not (low epistemic dependence) a function of their ability to accept the information given by their teachers, in a way similar to the previous study with Romanian students. It was predicted that a democratic style of teaching would obtain greater influence than an authoritarian style of teaching for students who perceived themselves in a state of low epistemic dependence. In Study 1, we also manipulated the legitimacy of the epistemic authority, based on the evaluation (positive vs. negative) of this epistemic authority. In Study 2, we examined if the predicted interaction hold when the task is explicitly diagnostic of cognitive ability.

\section{STUDY 1}

In a $2 \times 2 \times 2$ design, we manipulated the style of teaching (authoritarian vs. democratic), and high $v s$. low epistemic dependence subjects were identified on the basis of their belief that their competence is more or less a function of their ability to accept the information given by teachers. The legitimacy of the epistemic authority was also manipulated, subjects being informed that the epistemic authority was generally positively $v s$. negatively evaluated by his students. A first hypothesis could be that an epistemic authority would induce greater influence in transmitting knowledge to students when there is a correspondence between the (authoritarian vs. democratic) style of the authority and students' perceptions of their relation to the authority (high vs. low epistemic dependence). However, the style manipulation could hide a confounded variable. Indeed, in democratic Western societies, the authoritarian style may appear less legitimate, e.g., the source could be perceived as needing such a style in compensation for some poor pedagogical ability in the way to be convincing. Thus, an alternative hypothesis could simply be that a legitimate teacher would obtain greater influence in transmitting knowledge to students than an illegitimate one, regardless of specific properties of the style of teaching. Thus, manipulating the style of teaching and the legitimacy of the epistemic authority may help to delineate the relative weight of these two dimensions.

\section{Method}

\section{Participants}

Participants were 213 first year psychology female students (median age=19) from the University of Toulouse, France. The experimental design comprised three variables: The style of the epistemic authority (authoritarian vs. democratic), the legitimacy of the epistemic authority (legitimate $v s$. illegitimate), and the epistemic dependence state (low vs. high based on a median split). The two first variables were manipulated, while the third one was measured at the individual level. 


\section{Procedure}

After having answered some demographical questions (sex, age, and native country), all students filled out different tasks that appeared in the following sequence.

Initial representation of an ideal group of friends: All participants had to read the brief description of a study, and to guess the findings. To do this, they had to estimate the means of satisfaction observed among various groups of friends, as a function of the degree of leadership observed in these groups. Eight means of satisfaction were provided $(7.5-7.6-$ $7.7-7.9-9.5-9.6-9.8-9.9$ on a scale from $1=$ dissatisfied to $11=$ satisfied), and participants had to predict which mean corresponded to different percents of intra-group leadership (10\% - 20\% - 30\% - 40\% - 50\% - 60\% - 70\% - 80\%). Previous research using the paradigm of an ideal group of friend has clearly documented that students mainly believe that an ideal group of friends is a group without a leader (Mugny, Moliner, \& Flament, 1997).

Legitimacy of the epistemic authority: Before the findings of the fictitious study were presented, in the condition of illegitimacy students were informed that a professor whose scientific expertise was largely emphasized, namely M. Colson, was generally evaluated by his students as having poor pedagogical abilities. In the condition of legitimacy, they were informed that the professor was generally evaluated by his students as having high pedagogical abilities. One item immediately checked perceived legitimacy of the source: "The professor M. Colson is a good teacher" ( $1=$ no, $6=$ yes).

Style of the expert source: Bogus results of Colson's study were then presented. The study was said to have been published in a scientific, peer review journal, one of the most renowned in this discipline. A graph showed that the highest means of satisfaction were observed among groups of friends characterized by a high percent of intra-group leadership. The conclusion of the professor M. Colson was presented as a quoting. This conclusion informed that "an ideal group of friends is a group in which high levels of leadership are observed". In a condition, this conclusion was framed in an authoritarian style ("There are no possible doubts; an ideal group of friends is a group in which high levels of leadership are observed. Everybody has to accept this evidence. For instance, I would never pass a student who claimed the opposite, whatever are his or her arguments"). In another condition, this conclusion was framed in a democratic style ("There are no possible doubts; an ideal group of friends is a group in which high levels of leadership are observed. However, it is just the take home message of this study and everybody can accept or not this evidence. For instance, I would never refuse to pass a student who claimed the opposite, if his or her arguments are well-formulated"). One item was used to check the manipulation of the style of the epistemic authority: "In what extent do you think that the conclusions of professor M. Colson are authoritarian" ( $1=$ democratic, $6=$ authoritarian $)$.

Epistemic dependence: Perceived epistemic dependence was then measured by the following item: "A student's competence depends on his/her ability to admit knowledge provided by a scientific authority" (1=totally disagree, $8=$ totally agree).

Dependent variable: The main measure of this study concerned the representation of the ideal group of friends. Following the structural approach of social representations (Abric, 1994) the source's influence has been measured by the extent of centrality of the belief in equality in the representation of an ideal friendship group. Participants read the summary of a study related to the observation of a group of friends (Moliner, 1988). In this group of friends, high levels of satisfaction appear among its members, but clearly, there were also a leader, and hierarchical relationships between the leader and other members of the group. Participants were asked to indicate in what extent they judge that this group can be considered as an ideal group of friend ( $1=$ it is an ideal group of friends; $2=$ probably it is an ideal group of friends; $3=$ perhaps, it is an ideal group of friends; $4=$ perhaps, it is not an ideal group of friends; $5=$ probably it is not an ideal group of friends; $6=$ it is not an ideal group of friends). Lower 
scores on this measure indicated more influence of the epistemic authority, i.e., more appropriation of the contradictory information. Indeed, a modification in the centrality of equality supposes a cognitive restructuring process of the representational field (Quiamzade, 2003; Tafani \& Souchet, 2001), i.e., an effective elaboration of the information given by the source, beyond mere approval (Mugny, Tafani, Falomir, \& Layat, 2000).

\section{Results}

\section{Initial representation of "an ideal group of friends"}

According to the participants, higher levels of satisfaction would be observed among groups of friends with the lowest percentages of intra-group leadership $(10 \%$ to $40 \%)$ $(M=9.20, S D=.66)$, than among groups of friends with the highest percentages of intra-group leadership $(50 \%$ to $80 \%)(M=8.16, S D=.65)$. This difference was highly significant $[t(206)=11.35, p<.001]^{1}$.

\section{Check of the inductions}

The conclusion of professor M. Colson was perceived as more authoritarian in the condition of authoritarian style than in the condition of democratic style $[M=4.68, S D=1.10$, and $M=3.26, S D=1.37$, respectively, $F(1 ; 211)=69.43, p<.001]$. Furthermore, the source was perceived as a better teacher in the condition of legitimacy of the epistemic authority than in the condition of illegitimacy of the epistemic authority $[M=4.88, S D=.97$, and $M=2.91$, $S D=1.26$, respectively, $F(1 ; 209)=159.46, p<.001]$.

\section{Epistemic dependence split}

We first controlled by mean of a $2 \times 2$ factorial design the possible effects of the variables manipulated on the measure of epistemic dependence. Nor the main effects nor the interaction effect approached significance. A median split (low or high) was then computed on the measure of epistemic dependence (Median=4, $M=4.45, S D=1.82$ ). Participants with scores less or equal 4 were considered as sharing a representation of the relationship between students and teachers as marked by low epistemic dependence $(N=114, M=3.01)$ whereas the others were considered as sharing a representation of this relationship en terms of epistemic dependence $(N=99, M=6.10)$.

Table 1

Appropriation index (Study 1)

\begin{tabular}{lcc}
\hline & \multicolumn{2}{c}{ Perceived epistemic dependence } \\
\cline { 2 - 3 } & Low & High \\
\hline Authoritarian Style & $3.91(.14)$ & $3.29(.15)$ \\
& $N=59$ & $N=51$ \\
Democratic Style & $3.30(.14)$ & $3.35(.16)$ \\
& $N=55$ & $N=48$ \\
\hline
\end{tabular}

Note. The lower the number, the more the influence; Standard errors in parentheses.

\section{Information appropriation}

This median split and the two variables manipulated were used in an analysis of variance considering the representation of an ideal group of friends as the dependent variable. Results 
indicated a marginal effect of the median split $\left[F(1 ; 205)=3.68, p<.06, \eta^{2}=.01\right]$, a marginal effect of the teaching style $\left[F(1 ; 205)=3.39, p<.07, \eta^{2}=.01\right]$, and a marginal effect of teacher's legitimacy $\left[F(1 ; 205)=3.52, p<.07, \eta^{2}=.01\right]$. Participants low in epistemic dependence $(M=3.61, S E=.10)$ were less influenced than those high in epistemic dependence $(M=3.32$, $S E=.11)$. A democratic teaching style $(M=3.32, S E=.10)$ obtained greater influence than an authoritarian teaching style $(M=3.60, S E=.10)$. Surprisingly, the illegitimate teacher $(M=3.32$, $S E=.10)$ was more influential than the legitimate one $(M=3.60, S E=.10)$. Among all these variables, there was only one significant interaction between the epistemic dependence split (low or high) and the teaching style (democratic or authoritarian) $[F(1 ; 205)=4.96, p<.03$, $\left.\eta^{2}=.02\right]^{2}$. As predicted, a democratic teaching style $(M=3.30, S E=.14)$ obtained greater influence than an authoritarian style of teaching $(M=3.91, S E=.14)$, but only for participants low in epistemic dependence, $t(205)=3.14, p<.01$. No difference between the teaching style was observed for students high in epistemic dependence $[M=3.29, S E=.15$, and $M=3.35$, $S E=.16$, respectively, $t(205)=.37, n s]$. Another contrast was significant. It indicated that an authoritarian teaching style obtained greater influence on students high in epistemic dependence than on students low in epistemic dependence, $t(205)=2.97, p<.01$.

\section{Discussion of Study 1}

As predicted, we observed a significant interaction between the epistemic dependence and the style of teaching. The democratic style induced greater appropriation than the authoritarian style for participants low in epistemic dependence, whereas the reversed effect was not observed for students high in epistemic dependence. For them, the style had no significant effect. Legitimacy had only a main effect, but surprisingly, the illegitimate teacher was more influential than a legitimate one. A possible explanation would be that students could have been surprised by an unjustified negative evaluation by their peers and have compensated it through considering the source as having particularly high scientific skills, with the consequence that the experimental evidence became more convincing. Anyway, since it appears that legitimacy does not present the expected effect, and that it interferes neither with the style of the source nor with the predicted interaction, we do not consider further this marginal unexpected effect.

\section{STUDY 2}

As in Study 1, we manipulated the teaching style (authoritarian vs. democratic), and subjects were distinguished on the basis of their belief in the notion that their competence is more (high epistemic dependence) or less (low epistemic dependence) a function of their ability to accept the information given by their teachers. Four differences were introduced. First of all, the manipulation concerning the legitimacy of the source has been removed. Second, in Study 1, to ascertain that the item measuring perceived epistemic dependence took clear meaning for subjects, it has been introduced inside the scenario of the study, i.e., after the manipulations. Since this could be seen as a methodological weakness, and even if we controlled that there were no main nor interaction effects of the variables manipulated on the measure of epistemic dependence, in Study 2 it was introduced before any manipulation. Third, to insure that the effects are not just a French particularity but may concern more widely Western European cultures, the sample of Study 2 was of the same native language but from a different country, i.e., Switzerland. Finally, the diagnostic value of the task of influence was also manipulated: Targets were explicitly informed (or not) that the task was diagnostic of 
individual cognitive abilities. Based on the assumption that epistemic and identity stakes are greater when the nature of the task concerns the evaluation of highly valued academic domains (Monteil, 1988, Study 3; see also Monteil \& Huguet, 1999; indeed, value of the domains reflects intelligence as a gift that can be attributed to people who succeed in these domains, cf. Mugny \& Carugati, 1989), and that it accentuates differences between high and low epistemic dependence, it was expected that the interaction effect between informational dependence and the style of teaching should be more pronounced when the task was presented in such a way.

\section{Method}

\section{Participants}

They were 81 second year psychology students from the University of Geneva (a French speaking town, but not located in France), 68 women and 13 men, all native of Switzerland (median age $=21$ ). The experimental design comprised three variables: The style of the epistemic authority (authoritarian $v s$. democratic), the diagnostic aspect of the task of influence (diagnostic vs. not diagnostic), and the epistemic dependence measure (low vs. high based on a median split). The two first variables were manipulated, while the third one was measured at the personal level.

\section{Procedure}

After having answered some demographical questions (sex, age, and native country), all students filled out different tasks that appeared in the following sequence.

Epistemic dependence measure: The same item was used as in Study 1 ("A student's competence depends on his/her ability to admit knowledge provided by a scientific authority"). However, participants answered a 7-point scale (1: totally disagree, and 7: totally agree).

Diagnostic aspect of the task: The goal of the study was exposed in a brief paragraph. In the non diagnostic condition, the study was presented as "the validation of a new experimental protocol", with no reference to the ability of participants. In contrast, in the diagnostic condition, the study was presented as "a new and original IQ test" (see Steele \& Aronson, 1995). In this diagnostic condition, participants were informed that the goal of the study was to measure their intellectual abilities. To check the manipulation of the perception of the task as diagnostic or not of personal ability, one item was used: "Do you think that the difference between your predictions and M. Colson's results gives indications on your cognitive abilities?" $(1=$ no, and $8=$ yes $)$.

Initial attitude towards relationships in an "ideal group of friends": All participants had to read the brief description of the same M. Colson's experiment as in Study 1, and to guess the findings.

Style of the expert source: The two conditions of the style of influence (authoritarian $v s$. democratic) were exactly the same as in the first study. To check the manipulation of the style of the expert source, one item was used: "In what extent do you think that the conclusions of professor M. Colson are authoritarian" ( $1=$ not authoritarian, $8=$ authoritarian).

Dependent variable: The main dependent measure of this study concerned the representation of an ideal group of friends. The same measure of appropriation as in Study 1 was used. 


\section{Results}

\section{Check of the inductions}

Participants indicated that their predictions were not diagnostic of their cognitive ability $(M=2.16)$, and no main effect nor any interaction approached significance. In other words, the check of the diagnostic feature of the task failed to reach significance. In fact, as no effects appear whatever the dependent variable, the manipulation itself did not work. However, the manipulation style was effective. The conclusion of the source was perceived as more authoritarian in the condition of authoritarian style than in the condition of democratic style $[M=4.16, S D=2.24$, and $M=3.44, S D=2.27$, respectively, $F(1,79)=5.35, p<.03]$.

\section{Initial representation of "an ideal group of friends"}

According to the participants, higher levels of satisfaction would be observed among groups of friends with the lowest percentages of intra-group leadership (10\% to $40 \%)$ $(M=8.95, S D=.75)$, than among groups of friends with the highest percentages of intra-group leadership (50\% to $80 \%)(M=8.42, S D=.75)$. As expected, this difference was highly significant $[t(79)=3.17, p<.003]$.

\section{Epistemic dependence split}

A median split (low or high) was computed on the measure of epistemic dependence $(M d=3, M=2.70, S D=1.44)$. Participants with a score less or equal 2 were considered as sharing a representation of the relationship between students and teachers as marked by low epistemic dependence $(N=38, M=1.42)$ while the others were considered as sharing more a representation of this relationship in terms of epistemic dependence $(N=43, M=3.84)$. Even if manipulations were not yet introduced at this point, we however controlled by mean of 2 (style) $\times 2$ (diagnosticity) factorial design the possible effects of a sampling bias. Nor the main effects nor the interaction effect approached significance.

Table 2

Appropriation index (Study 2)

\begin{tabular}{lcc}
\hline & \multicolumn{2}{c}{ Perceived epistemic dependence } \\
\cline { 2 - 3 } & Low & High \\
\hline Authoritarian Style & $3.86(.24)$ & $3.45(.24)$ \\
& $N=22$ & $N=22$ \\
Democratic Style & $3.08(.28)$ & $3.88(.25)$ \\
& $N=16$ & $N=21$ \\
\hline
\end{tabular}

Note. The lower the number, the more the influence; Standard errors in parentheses.Information appropriation

This median split and the two variables manipulated were used in an analysis of variance using the representation of the ideal group of friends as the dependent variable. Contrary to the hypothesis, diagnosticity had no effect at all. Results indicated only a significant interaction between the style of the epistemic authority and the epistemic dependence measure $\left[F(1 ; 73)=5.31, p<.03, \eta^{2}=.06\right]^{3}$. As predicted, for participants low in epistemic dependence, the democratic teaching style $(M=3.08, S E=.28)$ obtained greater influence than the authoritarian teaching style $(M=3.86, S E=.24), t(73)=2.03, p<.05$. No differences between teaching styles were observed for students high in epistemic dependence $[M=3.88, S E=.25$, and $M=3.45, S E=.24$, respectively, $t(73)=1.16, n s]$. Another contrast was significant. It 
indicated that a democratic teaching style obtained greater influence on students low in epistemic dependence than on students high in epistemic dependence, $t(73)=2.12, p<.04$.

\section{Discussion of Study 2}

As in the first study, this second study revealed a significant interaction between the epistemic dependence and the teaching style. The democratic style induced greater appropriation than the authoritarian style for participants low in epistemic dependence, whereas the style had no significant effect for participants high in epistemic dependence. Diagnosticity had no main effect, nor did it interact with the predicted interaction. It would appear that our manipulation was not convincing enough to lead students to believe that the experimental situation was more or less diagnostic of their intelligence. Thus, one basic explanation could be that we failed to manipulate adequately this dimension. However, an alternative explanation would be that students were generally reluctant to declare that their cognitive abilities were at stake, since their predictions were evidently contradicted by the study proposed by the epistemic authority and could have made salient their incompetence (cf. Tafani, Mugny, \& Bellon, 1999). Finally, diagnosticity may be considered to induce two opposed dynamics that ask for further research. On one hand, it can motivate students to selfimprovement and thus induce learning and appropriation; on the other hand diagnosticity may render a threat to the identity salient and thus discourage learning since higher diagnosticity may be associated to increased self-incompetence in comparison to the highly competent source (Mugny, Quiamzade, Falomir, \& Tafani, 2006). Due to its total absence of effects in the present study, we do not consider further this manipulation.

\section{General discussion}

We have investigated in a Western European context the general hypothesis that appropriation of information provided by competent sources is more likely when the representation that targets have about the relationship with the source fits with the actual relationship (Quiamzade et al., 2004). In two studies we observed a significant interaction between the epistemic dependence and the teaching style. The democratic style induced greater appropriation than the authoritarian style for participants low in epistemic dependence, whereas this effect was not observed for students high in epistemic dependence: For them, the style had no significant effect.

Even if this appears to be a robust interaction effect, one additional contrast was significant, but it differs in both studies. In Study 1, the authoritarian style obtained greater influence on students high in epistemic dependence than on students low in epistemic dependence, whereas in Study 2, the democratic teaching style obtained greater influence on students low in epistemic dependence than on students high in epistemic dependence. In other words, in Study 1 a special rejection of influence appeared for students low in epistemic dependence confronted to the authoritarian style, whereas in Study 2 more appropriation was observed in front of the democratic style for the same students low in epistemic dependence. We cannot exclude different specific sensibilities to the various styles between the French (Study 1) and the Swiss (Study 2) samples, in spite of the fact that results are globally coherent across the two samples. Anyway, it must be noted that both significant contrasts are compatible with our general hypothesis. Because of the strong similarity of results between both studies, it is more acceptable to suppose that such a little difference may be the consequence of the sampling, and that each study just failed to show clear statistical significance in these contrasts. Another limitation would be that our samples were first year (Study 1) or second year students (Study 2), and that further research is needed to assess if the same psychological dimension underlying the relationship with epistemic authority (epistemic 
in-dependence) and the meaning given to the different styles also hold for higher degrees students.

In the context of the present studies, participants were students confronted with a source invested with epistemic authority. The relationship was of a cooperative nature since source and targets may be considered as having to join their efforts so that the transmission of knowledge be beneficial for the students. The interaction between message style and selfperceived epistemic dependence showed that subjects who perceive themselves to be less dependent (or more independent) who are confronted with a style allowing for some autonomy in the construction of knowledge appropriate the knowledge provided by the epistemic authority. When the style was authoritarian this contradicting information was not integrated by the same low dependent participants. The explanation of the lack of appropriation is that the authoritarian style is not appropriate to the representation students hold as to how knowledge should be transmitted to students who feel rather weakly dependent of the epistemic authority for forming a valid and competent judgment, even if they recognize they (still) have less competence than the source (cf. Tafani et al., 1999). The authoritarian style is inappropriate when targets are concerned with actively comparing, even negotiating, their previous knowledge with that of the source, and may lead them to interpret the relationship as an attempt to constrain them to be persuaded. The difference of points of view would be elaborated in relational terms since the source, rather than offering new information, is perceived as motivated to impose its point of view and to oblige the targets to renounce their previous beliefs. This persuasive constraint introduces an identity threat (cf. Falomir et al., 2002). When individuals believe themselves not to be dependent of the expert source, they consider themselves to be able to assess the validity of new information and this motivates them to reassert their self-competence. They cannot abandon the beliefs they actually hold, in a dynamic similar to psychological reactance (cf. Wicklund \& Brehm, 1968). The democratic style represents here a necessary way to discard such an identity threat.

When participants perceive a high dependence in their relationship with their teachers, we did not observe any more difference between both styles. Contrarily to Romanian participants previously studied, we did not observe a reverse effect, since the authoritarian style was not more efficient than the democratic style. This absence of dynamic due to the style in our French speaking samples may be attributed to cultural norms. Even if dependent individuals may be more motivated to change in front of a constraining source that guides them towards valid beliefs, appropriation would be inhibited because students expect to be treated in a deferent way and respected by the epistemic authority and cannot trust an authority that violates such expectations. As we have suggested this can be the consequence of cultural differences in perceived legitimacy of the authority between the two cultures. However, one limitation of the present results is that they do not allow to make a conclusion in this direction. More experiments are needed to investigate this possibility, for example by manipulating directly the legitimacy of the authority in the different cultural contexts.

In conclusion, in social transmission of knowledge contexts, competent sources (as well as experts) can, in particular due to task uncertainty, generate an informational dependence (Deutsch \& Gerard, 1955). They then may constitute relevant models or points of view for knowledge construction. However, this presupposes that the influence relationship be not mentally elaborated as an informational constraint (Mugny et al., 2003), as it is the case when perceived self-competence (Mugny et al., 2002) or epistemic independence (the present studies) increases ${ }^{4}$. If it is not, the potential threat to identity can be reduced, and the source can be perceived as providing relevant information even if there is an evident asymmetry in terms of source and target competence (or expertise) - an epistemic gap (Ellis \& Kruglanski, 1992). Instead of maintaining their position in a defensive way targets may then be motivated to appropriate the knowledge provided by the source, and to modify their beliefs on the basis of the conflicting contents. Is this not a way of both constructing more (supposedly) valid knowledge and acquiring self-competence? 


\section{Notes}

1 Precautionary analyses were performed separately for the 213 female and the 29 male participants on the initial representation of the ideal friendship group. A 2 (teacher's style) x 2 (teacher's legitimacy) x 2 (epistemic in/dependence) ANOVA showed no significant main or interaction effects for females. The same ANOVA revealed unexpected significant main and interaction effects for males. Since these effects constitute randomisation biases, male participants were discarded.

2 Similar results appear using regression analysis with the epistemic dependence as a continuous variable, $\beta=.48$, $t(212)=2.67, p<.01$.

3 Similar results appear using regression analysis with the epistemic dependence as a continuous variable, $\beta=.52$ $t(78)=2.09, p<.05$.

4 When self-competence increases to the point that targets believe themselves to have the same high competence as the source, they may experience a conflict of competencies (cf. Quiamzade \& Mugny, 2001). Indeed, when own judgments differ from those of a competent source, comparison with the source implies a certain probability that own judgements are erroneous. Targets who feel competent cannot give judgements inspired by those of the source, since it would imply the recognition of the source's correctness, a decrease in self-competence, and the possibility to loose self-esteem. They will instead engage in the social comparison process with the aim of invalidating the source and thus affirm self-validation (Butera \& Mugny, 2001), and even could be motivated to do so through differentiation from the source (Wicklund \& Brehm, 1968).

\section{References}

Abric, J.C. (1994). Les représentations sociales: Aspects théoriques. In J.C. Abric (Ed.), Pratiques sociales et représentations. Paris: Presses Universitaires de France.

Buchs, C., Falomir, J.M., Mugny, G., \& Quiamzade, A. (2002). Significations des positions initiales des cibles et dynamiques d'influence sociale dans une tâche d'aptitudes: L'hypothèse de correspondance. Nouvelle Revue de Psychologie Sociale, 1, 135-145.

Butera, F., \& Mugny, G. (2001). Conflict and social influences in hypothesis testing. In C.K.W. de Dreu \& N.K. de Vries (Eds.), Group consensus and minority influence implications for innovation. Oxford: Blackwell.

Cartwright, D., \& Zander, A. (1968). Power and influence in groups: Introduction. In D. Cartwright \& A. Zander (Eds.), Group dynamics. Research and Theory (3rd edition). New York: Harper and Row.

Deutsch, M., \& Gerard, H.B. (1955). A study of normative and informational social influences upon individual judgment. Journal of Abnormal and Social Psychology, 51, 629-636.

Ellis, S., \& Kruglanski, A. (1992). Self as an epistemic authority: Effects of experiential and instructional learning. Social Cognition, 10(4), 357-375.

Falomir, J.M., Butera, F., \& Mugny, G. (2002). Persuasive constraint and expert versus non-expert influence in intention to quit smoking. European Journal of Social Psychology, 32(2), 209-222.

French, J.R., \& Raven, B.H. (1959). The bases of social power. In D. Cartwright (Ed.), Studies in social power. Ann Arbor, Mich.: University of Michigan Press.

Garbarino, J., \& Bronfenbrenner, U. (1976). The socialization of moral judgment and behavior in cross-cultural perspective. In T. Lickona (Ed.), Moral development and behavior: Theory, research, and social issues. New York: Holt, Rinehart and Winston.

Hovland, C.I., Janis, I.L., \& Kelley, H.H. (1953). Communication and persuasion: Psychological studies of opinion change. New Haven: Yale University Press.

Insko, C.A., Drenan, S., Solomon, M.R., Smith, R., \& Wade, T.J. (1983). Conformity as a function of consistency of positive self-evaluation with being liked and being right. Journal of Experimental Social Psychology, 19(4), 342358.

Kelman, H.C. (1958). Compliance, identification, and internalisation: Three processes of attitude change. Journal of Conflict Resolution, 2, 51-60.

Kitchener, K.S., \& King, P. (1981). Reflective judgment: Concepts of justification and their relationship to age and education. Journal of Applied Developmental Psychology, 2(2), 89-116. 
Kitchener, K.S., King, P., Wood, P.K., \& Davison, M.L. (1989). Sequentiality and consistency in the development of reflective judgment: A six-year longitudinal study. Journal of Applied Developmental Psychology, 10(1), 73-95.

Kruglanski, A.W. (1989). Lay epistemics and human knowledge: Cognitive and motivational bases. New York: Plenum Press.

McGuire, W.J. (1985). Attitudes and attitude change. In G. Lindzey \& E. Aronson (Eds.), The handbook of social psychology (3rd edition, vol. 2). New York: Erlbaum.

Moliner, P. (1988). Validation expérimentale de l'hypothèse du noyau central des représentations sociales. Bulletin de Psychologie, 41(387), 759-762.

Monteil, J.M. (1988). Social comparison, individual strategies and socio-cognitive mediations: An effect of behavioral differentiations at schools. European Journal of Psychology of Education, 3(1), 3-18.

Monteil, J.M., \& Huguet, P. (1999). Social context and cognitive performance. Towards a social psychology of cognition. Hove: Psychology Press.

Mugny, G., Carugati, F. (1989). Social representations of intelligence. Cambridge: Cambridge University Press. Paris: Editions de la Maison des Sciences de l'Homme.

Mugny, G., Moliner, P., \& Flament, C. (1997). De la pertinence des processus d'influence sociale dans la dynamique des représentations sociales. Revue Internationale de Psychologie Sociale, 10, 31-49.

Mugny, G., Quiamzade, A., \& Trandafir, A. (2006). Dépendance informationnelle et styles de comportement dans l'influence sociale. Psychologie Sociale (in press).

Mugny, G., Quiamzade, A., Falomir, J.M., Tafani, E. (2006). Diagnosticité de la tâche dans l'évaluation des compétences et dépendance informationnelle. International Review of Social Psychology, 19(2), 5-26.

Mugny, G., Tafani, E., Falomir, J.-M., \& Layat, C. (2000). Source credibility, social comparison and social influence. International Review of Social Psychology, 13, 151-175.

Mugny, G., Butera, F., Quiamzade, A., Dragulescu, A., \& Tomei, A. (2003). Comparaisons sociales des compétences et dynamiques d'influence sociale dans les tâches d'aptitudes. Année Psychologique, 103(3), 469-496.

Mugny, G., Quiamzade, A., Pigière, D., Dragulescu, A., \& Buchs, C. (2002). Self-competence, interaction style and expert social influence: Toward a correspondence hypothesis. Swiss Journal of Psychology, 61(3), 153-166.

Quiamzade, A. (2003). Mesure de la réorganisation du noyau central d'une représentation sociale: Mise en cause de Moliner (1988). International Review of Social Psychology, 16(4), 25-46.

Quiamzade, A., \& Mugny, G. (2001). Social influence dynamics in aptitude tasks. Social Psychology of Education, 4(3-4), 311-334.

Quiamzade, A., Mugny, G., \& Buchs, C. (2005). Correspondance entre rapport social et auto-compétence dans la transmission de savoir par une autorité épistémique: Une extension. Année Psychologique, 105, 423-449.

Quiamzade, A., Mugny, G., Dragulescu A., \& Buchs, C. (2003). Interaction styles and expert social influence. European Journal of Psychology of Education, 18(4), 389-404.

Quiamzade, A., Mugny, G., Falomir, J.M., Invernizzi, F., Buchs C., \& Dragulescu, A. (2004). Correspondance entre style d'influence et significations des positions initiales de la cible: Le cas des sources expertes. In J.L. Beauvois, R.V. Joule, \& J.M. Monteil (Eds.), Perspectives cognitives et conduites sociales (vol. 9). Rennes: Presses Universitaires de Rennes.

Shouval, R., Venaki, S.K., Bronfenbrenner, U., Devereux, E.C., \& Kiely, E. (1975). Anomalous reactions to social pressure of Israeli and Soviet children raised in family versus collective settings. Journal of Personality and Social Psychology, 32(3), 477-489.

Steele, C.M., \& Aronson, J. (1995). Stereotype threat and the intellectual test performance of African Americans. Journal of Personality and Social Psychology, 69(5), 797-811.

Tafani, E., \& Souchet, L. (2001). Changement d'attitude et dynamique représentationnelle. In P. Moliner (Ed.), La dynamique des représentations sociales (pp. 59-88). Grenoble: Presses Universitaires de Grenoble.

Tafani, E., Mugny, G., \& Bellon, S. (1999). Irréversibilité du changement et enjeux identitaires dans l'influence sociale sur une représentation sociale. Psychologie et Société, 1, 73-104. 
Tomasetto, C. (2004). Influence style and students' orientation toward extra-curricular activities: An application of the correspondence hypothesis. European Journal of Psychology of Education, 19(2), 133-145.

Tyler, T.R. (1997). The psychology of legitimacy: A relational perspective on voluntary deference to authorities. Personality and Social Psychology Review, 1(4), 323-345.

Wicklund, R.A., \& Brehm, J.W. (1968). Attitude change as a function of felt competence and threat to attitudinal freedom. Journal of Experimental Social Psychology, 4, 64-75.

Il est argué qu'une autorité épistémique devrait induire davantage d'influence en transmettant des connaissances à des étudiants lorsqu'il existe une correspondance entre le style (autoritaire ou démocratique) de l'autorité et la perception que ceux-ci ont de leurs relations avec l'autorité, en termes de dépendance ou d'indépendance épistémiques. Comme prédit, dans deux études il est montré que les étudiants qui se jugent dans un état d'indépendance épistémique à l'égard de leurs enseignants sont plus influencés par le style démocratique que par le style autoritaire d'enseignement. Cette différence dans l'appropriation $n$ 'est pas observée chez les étudiants qui se perçoivent dans un état de dépendance épistémique à l'égard de l'autorité.

Key words: Appropriation, Democratic and authoritarian style, Epistemic (In)dependence.

Received: June 2005

Revision received: January 2006

Gabriel Mugny. Université de Genève, F.P.S.E., 40 bvd. du Pont d'Arve, 1205 Geneva, Switzerland. E-mail: Gabriel.Mugny@pse.unige.ch; Web site: www.unige.ch/fapse/psychosociale/welcome.htm

Current theme of research:

Conflict elaboration. Social influence. Social development of knowledge. Social representations.

Most relevant publications in the field of Psychology of Education:

Buchs, C., Butera, F., Mugny G., \& Darnon, C. (2004). Conflict elaboration and cognitive outcomes. Theory Into Practice, 43(1), 23-30.

Buchs, C., Falomir, J.M., Mugny, G., \& Quiamzade, A. (2002). Significations des positions initiales des cibles et dynamiques d'influence sociale dans une tâche d'aptitudes: L'hypothese de correspondance. Nouvelle Revue de Psychologie Sociale, 1, 134-145.

Butera, F., \& Mugny, G. (Eds.). (2001). Social influence in social reality: Promoting individual and social change. Seattle: Hogrefe \& Huber.

Mugny, G., Butera, F., Quiamzade, A., Dragulescu, A., \& Tomei, A. (2003). Comparaisons sociales des compétences et dynamiques d'influence sociale dans les tâches d'aptitudes. Année Psychologique, 103(3), 469-496.

Mugny, G., Quiamzade, A., Dragulescu, A., Pigiere, D., \& Buchs, C. (2002). Self-competence, interaction style and expert social influence: Toward a correspondence hypothesis. Swiss Journal of Psychology, 61, 153-166. 
Armand Chatard. Université de Genève, F.P.S.E., 40 bvd. du Pont d'Arve, 1205 Geneva, Switzerland. E-mail: Armand.Chatard@pse.unige.ch; Web site: www.unige.ch/fapse/psychosociale/welcome.htm

Current theme of research:

Group socialization. Normative influence. Stereotyping and social identity dynamics in status hierarchies. Gender differences, social dominance, and social comparison.

Most relevant publications in the field of Psychology of Education:

Baudelot, C., Leclercq, F., Chatard, A., Gobille, B., \& Satchkova, E. (2005). Les effets de l'éducation. Paris: La documentation française.

Chatard, A. (2004). L'orientation scolaire sous l'emprise des stéréotypes. In M.C. Toczek \& D. Martinot (Eds.), Le défi éducatif: Des situations pour réussir. Paris: Armand Colin.

Chatard, A., Guimond, S., \& Martinot, D. (2005). Impact de la féminisation lexicale des professions sur l'auto-efficacité des élèves: Une remise en cause de l'universalisme masculin. L'Année Psychologique, 105, 249-272.

Chatard, A., Quiamzade, A., \& Mugny, G. (in press). Les effets de l'éducation sur les attitudes sociopolitiques des étudiants: Le cas de deux universités en Roumanie. Forthcoming in L'Année Psychologique.

Guimond, S., Chatard, A., Martinot, D., Crisp, R., \& Redersdorff, S. (2006). Social comparison, self-stereotyping, and gender differences in self-construal. Journal of Personality and Social Psychology, 90, 221-242.

Alain Quiamzade. Université de Genève, F.P.S.E., 40 bvd. du Pont d'Arve, 1205 Geneva, Switzerland. E-mail: Alain.Quiamzade@pse.unige.ch; Web site: www.unige.ch/fapse/psychosociale/welcome.htm

Current theme of research:

Social comparison. Social influence. Minority influence. Attribution processes. Social representations.

Most relevant publications in the field of Psychology of Education:

Quiamzade, A., \& Mugny, G. (2001). Social influence dynamics in aptitude tasks. Social Psychology of Education, 4, 311-334.

Quiamzade, A., \& Mugny, G. (2004). Les niveaux d'analyse: Le cas de l'influence des sources compétentes. Nouvelle Revue de Psychologie Sociale, 3(1-2), 65-72.

Quiamzade, A., Mugny, G., \& Buchs, C. (2005). Correspondance entre rapport social et autocompétence dans la transmission de savoir par une autorité épistémique: Une extension. L'Année Psychologique,423-449.

Quiamzade, A., Mugny, G., Dragulescu, A., \& Buchs, C. (2003). Interaction styles and expert social influence. European Journal of Psychology of Education, 18(4), 389-404.

Quiamzade, A., Mugny, G., Falomir, J.M., Invernizzi, F., Buchs, C., \& Dragulescu, A. (2004). Correspondance entre style d'influence et significations des positions initiales de la cible: Le cas des sources expertes. In J.L. Beauvois, R.Y. Joule, \& J.M. Monteil (Eds.), Perspectives cognitives et conduites sociales (vol. 9, pp. 341-363). Rennes: Presses Universitaires de Rennes. 